Scientific Review - Engineering and Environmental Sciences (2018), 27 (1), 91-99

Sci. Rev. Eng. Env. Sci. (2018), 27 (1)

Przegląd Naukowy - Inżynieria i Kształtowanie Środowiska (2018), 27 (1), 91-99

Prz. Nauk. Inż. Kszt. Środ. (2018), 27 (1)

http://iks.pn.sggw.pl

DOI 10.22630/PNIKS.2018.27.1.9

\title{
Waldemar JASKÓŁOWSKI
}

Wydział Inżynierii Bezpieczeństwa Pożarowego, Szkoła Główna Służby Pożarniczej

w Warszawie

Faculty of Fire Safety Engineering, The Main School of Fire Service

\section{Ocena toksyczności środowiska pożarowego - problem nie do rozwiązania? \\ Assessment of fire environment toxicity - an unsolvable problem?}

Słowa kluczowe: toksyczność, bezpieczeństwo pożarowe, środowisko pożarowe, ewakuacja

Key words: fire toxicity, fire safety, fire evacuation

\section{Wprowadzenie}

Pożar niezależnie od miejsca, w którym powstanie, jest „sprawcą" wielu zagrożeń dla ludzi, środowiska oraz technicznej i budowlanej infrastruktury. Analiza przyczyn wypadków śmiertelnych podczas pożarów w obiektach budowlanych wskazuje że, około $80 \%$ ofiar zmarło w wyniku kontaktu z produktami toksycznymi powstałymi podczas rozkładu termicznego i spalania (Kobes, Helsloot, de Vries i Post, 2010). Paradoksalnie we współczesnych budynkach to zagrożenie jest większe niż kilkadziesiąt lat wcześniej $\mathrm{z}$ uwagi na to, że obecnie $w$ budownictwie stosuje się głównie wyroby z tworzyw sztucznych (Stec, 2017). Należy zaznaczyć, że tworzywa sztuczne są nie tylko źródłem większego zagrożenia z uwagi na toksyczność produktów spalania, ale także w porównaniu do drewna cechuja się znacznie większą wartością ciepła spalania. W efekcie wszędzie tam, gdzie użyto wyrobów budowlanych z tworzyw sztucznych, szybkość tworzenia się zagrożeń pożarowych jest większa.

Zapewnienie bezpieczeństwa ludzi podczas pożaru dotyczy w równym stopniu mieszkańców, użytkowników, gości, widzów, a także zastępów państwowej straży pożarnej (PSP) biorących udział w działaniach związanych z prowadzeniem akcji ratowniczej. Jest to jeden z fundamentalnych obowiązków inwestorów, właścicieli budynków. Głównym źródłem kształtującym kryteria bezpieczeństwa pożarowego są regulacje 
prawne. Na podstawie $\S 207$ ust. 1 rozporządzenia Ministra Infrastruktury z 2002 roku w sprawie warunków technicznych (Dz.U. $2002 \mathrm{nr}$ 75, poz. 690) można stwierdzić, że zostanie zapewniony właściwy poziom bezpieczeństwa pożarowego wtedy, gdy zastosowany zespół rozwiązań techniczno-budowlanych w budynku i urządzeniach z nim związanych zapewnia $\mathrm{w}$ razie pożaru:

- nośność konstrukcji przez czas wynikający z właściwych przepisów,

- ograniczenie rozprzestrzeniania się ognia i dymu w budynku,

- ograniczenie rozprzestrzeniania się ognia na sąsiednie budynki,

- możliwość bezpiecznej i skutecznej ewakuacji (osoby znajdujące się wewnątrz mogły opuścić obiekt budowlany lub być uratowane $\mathrm{w}$ inny sposób),

- bezpieczeństwo ekip ratowniczych.

Z powyższego wynika, że stan bezpieczeństwa pożarowego budynku jest określony przez stan środowiska (z uwagi na jego oddziaływanie na ludzi) oraz stan konstrukcji (z uwagi na zdolność do przenoszenia obciazzeń).

Możliwość bezpiecznej i skutecznej ewakuacji jest jednym z najistotniejszych celów bezpieczeństwa pożarowego. $\mathrm{Na}$ skuteczną i bezpieczną ewakuację ludzi z budynków ma wpływ bardzo wiele czynników. Oprócz cech indywidualnych ludzi (osobowość, świadomość, zdolność percepcji i poruszania się, wiedza i doświadczenie, bariera językowa), charakterystyki budynku (wyposażenie $\mathrm{w}$ techniczne systemy zabezpieczeń ppoż, liczba ludzi przebywających w obiekcie, kubatura, istnienie punktu zbornego przewidzianego $\mathrm{W}$ procedu- rze ewakuacyjnej) na ewakuację mają wpływ cechy pożarowe charakteryzujące elementy wykończenia wnętrz. Muszą one spełniać określone wymagania w zakresie właściwości termokinetycznych, dymotwórczych, toksycznych. $\mathrm{Z}$ punktu widzenia bezpieczeństwa pożarowego najważniejsza jest pierwsza faza rozwoju pożaru.

Toksyczność środowiska pożarowego jest jednym $\mathrm{z}$ najważniejszych, a może najważniejszym aspektem, który wymaga analizy i oceny z punktu widzenia bezpieczeństwa pożarowego.

O toksyczności środowiska pożarowego decyduje wiele czynników, które można określić jako materiałowe i pozamateriałowe.

\section{Toksyczność środowiska pożarowego - teraźniejszość}

W odniesieniu do elementów wykończenia wnętrza $\mathrm{w}$ zakresie wymagań dotyczących toksyczności określone są czytelne wymagania (kryteria). W § 258.1 cytowanego rozporzadzenia stwierdza się że, „w strefach pożarowych ZL I, ZL II, ZL III i ZL V stosowanie do wykończenia wnętrz materiałów latwo zapalnych, których produkty rozkładu termicznego są bardzo toksyczne lub intensywnie dymiące, jest zabronione” oraz w pkt. 2 „Na drogach komunikacji ogólnej, służących celom ewakuacji, stosowanie materiałów i wyrobów budowlanych łatwo zapalnych jest zabronione". Taka konstrukcja wymagań prawnych powoduje, że realizacja celu zawartego we właściwych przepisach odnoszących się do elementów wykoń- 
czenia wnętrz i toksyczności środowiska pożarowego jest nieskomplikowana, jeśli chodzi o realizację przez inwestorów czy użytkowników.

„Wystarczy” przeprowadzić badania z wykorzystaniem metodyki pomiarowej opisanej w normie PN-88/B-02855, których celem będzie uzyskanie odpowiedniej klasyfikacji (umiarkowanie toksyczny, toksyczny, bardzo toksyczny) materiału (wyrobu). Należy podkreślić, że norma, o której mowa została wycofana dwa lata temu. Jej ranga jest wciąż jednak bardzo duża, gdyż wyniki przeprowadzone z zastosowaniem tej metody są nadal podstawą oceny wyrobów budowlanych pod względem toksyczności.

Zasada metody polega na ilościowym, chemicznym oznaczaniu wybranych selektywnie produktów rozkładu termicznego i spalania $\left(\mathrm{CO}, \mathrm{CO}_{2}, \mathrm{HCN}\right.$, $\mathrm{HCl}, \mathrm{NO}_{\mathrm{x}}, \mathrm{SO}_{\mathrm{x}}$ ). Rodzaj badanych gazów zasadniczo nie odbiega od innych określonych w normach europejskich i światowych. Badanie przeprowadza się w trzech zakresach temperatury 450, 550 i $750^{\circ} \mathrm{C}$.

Przeprowadzenie procedury badawczej, uzyskanie wymaganych rezultatów i przyjęcie założenia, że produkty, które uzyskały cechę umiarkowanie toksyczne, nie stanowią w czasie pożaru istotnego problemu jest daleko niewystarczające.

Analiza tego aspektu środowiska pożarowego wymaga zastosowania strategii stworzonej na podstawie doświadczeń inżynierii pożarowej i oceny celów funkcjonalnych (ang. performance based codes). Obecnie w tym obszarze strategia pożarowa jest opracowywana wyłącznie według przepisów (ang. prespective based codes).

\section{Toksyczność środowiska pożarowego - przyszlość}

Dotychczas nie udało się w Unii Europejskiej wypracować jednej powszechnej metody badawczej do analizy składu chemicznego i ilości tworzących się produktów w trakcie pożaru (spalania) (Hull i Paul, 2007). Przyjęta w ostatnich latach tzw. europejska klasyfikacja ogniowa(PN-EN 13501-1+A1:2010) wyrobów (materiałów) budowlanych (w Polsce wprowadzona normą PN ISO 13501:2012) zmieniła diametralnie podejście do oceny właściwości pożarowych wyrobów budowlanych. Ogólnie można stwierdzić, że klasyfikacja materiałów budowlanych z wyłączeniem materiałów wykończeniowych stosowanych na podłogi powstała na podstawie wyników badań właściwości termokinetycznych, których miernikiem jest ciepło spalania oraz wskaźnik FIGRA (ang. fire growth rate index), właściwości dymotwórczych, określonych wskaźnikiem SMOGRA (ang. smoke growth rate), oraz oceny zdolności do tworzenia kropli. Analiza tego dokumentu utwierdza w przekonaniu, że problem oceny toksyczności nie został rozwiązany i pozostaje zasadniczo ten sam od lat. Jak podejść w praktyce do problematyki toksyczności środowiska pożarowego z udziałem różnych materiałów budowlanych? Odpowiedź na to pytanie jest bardzo trudna. Na poziom zagrożenia toksycznego ma wpływ nie tylko skład chemiczny paliwa, ale także stężenie tlenu, temperatura środowiska pożarowego, faza rozwoju pożaru. Należy domniemywać, że efekt oddziaływania produktów toksycznych będzie inny w przypadku kobiet i mężczyzn, osób małoletnich i dorosłych, młodszych i starszych. 
Niezależnie od przyjętej strategii w zakresie bezpieczeństwa pożarowego to analiza toksyczności środowiska pożarowego powinna zaczać się od analizy składu chemicznego i ilości tworzących się produktów rozkładu termicznego i spalania. Nastręcza ona wiele problemów, gdyż w warunkach pożarowych tworzą się niejednokrotnie setki produktów toksycznych pod względem jakościowym i ilościowym. Praktycznie nie jest możliwe zidentyfikowanie i oszacowanie ilości wszystkich produktów powstałych podczas spalania, dlatego też przyjęto w Polsce i na świecie szacowanie toksyczności, uwzględniając wybrane związki chemiczne. Do najważniejszych podlegających ocenie należą: $\mathrm{CO}$, $\mathrm{CO}_{2}, \mathrm{HCN}, \mathrm{NO}_{\mathrm{x}}, \mathrm{SO}_{\mathrm{x}}, \mathrm{HCl}, \mathrm{HBr}, \mathrm{HF}$, formaldehyd oraz akroleina. W niektórych źródłach wskazuje się na dodatkowe związki chemiczne (toksykanty), od których można zaliczyć: aldehydy, akrylonitryl, amoniak, tlenki fosforu, siarkowodór, dwusiarczek węgla, kwas mrówkowy, fenol, benzen, toluen oraz styren. Analizą można objąć także inne dodatkowe produkty, które według wiedzy inżynierskiej powinny być nią objęte. Produkty toksyczne powstające podczas pożaru można sklasyfikować według fizjologicznych efektów, które powodują w ludzkim organizmie na duszące i drażniące (PN EN 60695-7-1:2007).

Badania składu i ilości produktów toksycznych można podzielić na dwie grupy. Pierwsza dotyczy testów w małej skali, w których za pomocą odpowiedniej aparatury generowane produkty spalania są filtrowane i przepuszczane przez wiele czujników mierzących wartości szukanych parametrów. Druga natomiast dotyczy testów w dużej skali, w których mierzone wartości są przeprowadzane w zaadaptowanych rzeczywistych warunkach. Te jednak stosowane są znacznie rzadziej ze względu na koszty związane z ich realizacją. Ilość i skład chemiczny produktów rozkładu termicznego i spalania tworzących się podczas spalania wyrobów budowlanych w warunkach pożarowych jest pochodną nie tylko właściwości fizycznych i chemicznych tego materiału, ale także innych czynników pozamateriałowych, do których można zaliczyć przede wszystkim warunki, wjakich przebiega pożar (rodzaj spalania, wentylacja, geometria pomieszczenia).

Zmienna dynamika rozwoju (fazy pożaru), efekty wzajemnego oddziaływania produktów spalania (synergizmu, sumujące) to kolejne czynniki, które wpływają na skład i ilość gazów pożarowych. Przykładowo podczas spalania pianki poliuretanowej $\mathrm{w}$ temperaturze $400^{\circ} \mathrm{C}$ w produktach spalania przeważają izocyjaniany i nitryle. W wyższej temperaturze dominującym produktem jest HCN. W jeszcze wyższej temperaturze przeważają tlenki azotu. Podczas całkowitego spalania tworzyw sztucznych zawierających jedynie $\mathrm{C}, \mathrm{H}$ i O powstaje tylko $\mathrm{CO}_{2}$ i woda. Niecałkowite spalanie tej samej grupy materiałów diametralnie zmienia skład gazów pożarowych. Wtedy przewage zyskują: $\mathrm{CO}$, węglowodory, aldehydy i cząstki stałe (Hull i Keith, 2007). Powyższy przykład dowodzi, że temperatura i stężenie tlenu istotnie determinują skład produktów rozkładu termicznego.

Od chwili zainicjowania pożar może przebiegać w różny sposób uzależniony od warunków środowiskowych, a także od fizycznego rozmieszczenia materiałów palnych. 
Dzięki klasyfikacji faz pożaru (tab.) można wybrać odpowiednie warunki do stosowania $\mathrm{w}$ próbach $\mathrm{w}$ skali laboratoryjnej $\mathrm{w}$ celu uzyskania możliwie najlepszej zbieżności z pożarami w pełnej skali. W trakcie pożaru dochodzi do wielu złożonych i wzajemnie powiązanych zjawisk fizycznych i chemicznych. Powoduje to znaczną trudność w symulowaniu wszystkich aspektów pożaru w aparaturze o skali laboratoryjnej. Prawidłowość modelu pożaru jest jedynym z najtrudniejszych problemów technicznych związanych ze wszystkimi badaniami pożarowymi, nie tylko w odniesieniu do szacowania toksyczności środowiska pożarowego.

Należy podkreślić, że w stosowanych metodach badawczych w trakcie badań toksyczności nie uwzględnia się spadku stężenia tlenu, które $\mathrm{w}$ warunkach pożarowych może powodować określone dysfunkcje organizmów żywych (np. hipoksję). Reasumując, przy wyborze metod badawczych wyrobów budowlanych zaleca się, aby dla każdej metody rozważyć następujące problemy:

- czy metoda badawcza odwzorowuje fazę pożaru będącą przedmiotem zainteresowania?

- czy rezultatem badań są wyniki, które będziemy mogli wykorzystać do oceny pod kątem bezpieczeństwa pożarowego?

Jeżeli odpowiedź na którekolwiek z tych pytań brzmi nie, to rozważana metoda wymaga modyfikacji albo należy rozważyć inną alternatywną metodę. Zastosowana metoda badawcza powinna ściśle odzwierciedlać określoną fazę rozwoju pożaru. $Z$ tabeli można wybrać warunki do stosowania w próbach w skali laboratoryjnej w celu uzyskania możliwie najlepszej zbieżności z pożarami

TABELA. Ogólna klasyfikacja pożaru (opracowanie własne na podstawie PN-EN 60695-7-1:2007)

TABLE. The general fire classfication (own elaboration on the basis of PN-EN 60695-7-1:2007)

\begin{tabular}{|c|c|c|c|c|c|}
\hline \multicolumn{2}{|c|}{$\begin{array}{l}\text { Faza pożaru } \\
\text { Fire phase }\end{array}$} & $\begin{array}{l}\text { Tlen } \\
\text { Oxy- } \\
\text { gen } \\
{[\%]}\end{array}$ & $\mathrm{CO} / \mathrm{CO}_{2}$ & $\begin{array}{c}\text { Temperatura } \\
\text { Temperature } \\
{\left[{ }^{\circ} \mathrm{C}\right]}\end{array}$ & $\begin{array}{c}\text { Natężenie } \\
\text { promieniowania } \\
\text { Radiation intensity } \\
{\left[\mathrm{kW} \cdot \mathrm{m}^{-2}\right]}\end{array}$ \\
\hline \multirow{4}{*}{$\begin{array}{l}\text { Faza } 1 \\
\text { Phase } 1\end{array}$} & \multicolumn{5}{|c|}{ rozkład bezpłomieniowy } \\
\hline & $\begin{array}{l}\text { tlenie } \\
\text { (samopodtrzymujące) }\end{array}$ & 21 & nie dotyczy & $<100$ & nie dotyczy \\
\hline & $\begin{array}{l}\text { bezpłomieniowy } \\
\text { utleniający }\end{array}$ & $5-10$ & nie dotyczy & $<500$ & $<25$ \\
\hline & $\begin{array}{l}\text { bezpłomieniowy } \\
\text { (pirolityczny) }\end{array}$ & $<5$ & nie dotyczy & $<1000$ & nie dotyczy \\
\hline $\begin{array}{l}\text { Faza } 2 \\
\text { Phase } 2\end{array}$ & $\begin{array}{l}\text { pożar rozwijający się } \\
\text { (palący się płomieniem) }\end{array}$ & $10-15$ & $100 / 200$ & $400-600$ & $20-40$ \\
\hline \multirow{3}{*}{$\begin{array}{l}\text { Faza } 3 \\
\text { Phase } 3\end{array}$} & \multicolumn{5}{|c|}{ pożar całkowicie rozwinięty (palący się płomieniem) } \\
\hline & $\begin{array}{l}\text { względnie małe } \\
\text { przewietrzenie }\end{array}$ & $1-5$ & $<10$ & $600-900$ & $40-70$ \\
\hline & $\begin{array}{l}\text { względnie duże } \\
\text { przewietrzenie }\end{array}$ & $5-10$ & $<100$ & $600-1200$ & $50-150$ \\
\hline
\end{tabular}


w pełnej skali. Trzeba mieć świadomość, że pożar rozwija się na bardzo wiele sposobów zależnych głównie od źródła inicjacji pożaru, składu materiałów, ich ilości, orientacji i powierzchni, geometrii pomieszczenia, położenia i wielkości otworów wentylacyjnych. Rozwój pożaru odnosi się do wzrostu w czasie wartości parametrów opisujących pożar. Biorąc pod uwagę powyższe, trudno jest symulować wszystkie aspekty pożaru z wykorzystaniem metodyk badawczych w skali laboratoryjnej.

Odrębnym problem jest ocena toksyczności powstałych produktów spalania. Może być ona przeprowadzona za pomoca analizy chemicznej albo na podstawie wyników testów na zwierzętach. Ta pierwsza ocena wymaga porównania otrzymanych wartości doświadczalnych $\mathrm{z}$ danymi zebranymi podczas badań na zwierzętach, analizy wypadków, pożarów z ofiarami śmiertelnymi. W obu przypadkach wymagana jest ekstrapolacja. Reakcja zwierząt nie równa się reakcji ludzi. Ponadto trzeba mieć świadomość, że osoby poddane oddziaływaniu toksycznych gazów należą do często różnych grup: młodzi, starsi, niepełnosprawni, pod wpływem alkoholu. Ich reakcje mogą różnić się i to trzeba wziąć pod uwagę. Poza tym zwierzęta wykorzystywane do celów eksperymentalnych są na ogół dorosłe i zdrowe. Na szczęście tylko w niektórych krajach (USA, Japonia, Chiny) do oceny toksyczności produktów spalania wciąż wykorzystuje się zwierzęta. W Europie te oceny przeprowadza się poprzez analizę chemiczną.
Wyniki badań najczęściej wyrażane są poprzez określenie stężenia gazu toksycznego $\left[\mu \mathrm{l} \cdot 1^{-1}\right.$ lub $\left.\mathrm{g} \cdot \mathrm{m}^{-3}\right]$ lub emisji właściwej $\left[\mathrm{g} \cdot \mathrm{g}^{-1}\right]$. Podstawą koncepcji szacowania toksyczności środowiska pożarowego jest określanie w warunkach pożarowych:

- cząstkowej dawki efektywnej-FED (ang. fractional effectice dose) odzwierciedlającej działanie gazów duszących (narkotycznych): $\mathrm{CO}$ i HCN,

- cząstkowego stężenia efektywnego - FEC (ang. fractional effective concentration) charakteryzującego działanie gazów drażniących.

Skuteczna dawka cząstkowa została zdefiniowana jako stosunek stężenia i czasu przeznaczonego dla gazowych toksycznych produktów spalania w określonym czasie ekspozycji, którego skutkiem jest śmierć 50\% badanych zwierząt narażonych na toksyczny czynnik w określonym czasie. Z kolei norma PN-EN 60695-7-1:2007 definiuje FED jako stosunek dawki narażeniowej duszącego środka toksycznego do takiej, przy której można spodziewać się określonego skutku narażonego podmiotu o przeciętnej wrażliwości. Podstawą modelu FED jest przyjęcie, że końcowe działanie gazów drażniących jest efektem sumowania udziałów cząstkowych otrzymanych przez podzielenie aktualnego stężenia przez stężenie przyjmowane jako krytyczne. Jeśli taka suma osiagnie wartość 1, to przyjmuje się, że środowisko pożaru z uwagi na toksyczność jest wybitnie drażniące i powoduje skrajne skutki, które sprowadzają się do znacznego spowolnienie ewakuacji. 
Matematycznie FED można wyrazić za pomocą następującego wzoru:

$$
X_{F E D}=\sum_{i=1}^{n} \sum_{t_{1}}^{t_{2}} \frac{C_{i}}{(C t)_{i}} \Delta t
$$

gdzie:

$C_{i}$ - średnie stężenie składnika $i\left[\mu 1 \cdot 1^{-1}\right.$ lub $\left.\mathrm{g} \cdot \mathrm{m}^{-3}\right] \mathrm{w}$ analizowanym przedziale czasowym [min],

$(C t)_{\mathrm{i}}$ - maksymalne dopuszczalne stężenie składnika toksycznego umożliwiające bezpieczną ewakuację $\left[\mu 1 \cdot 1^{-1}\right.$ lub $\left.\mathrm{g} \cdot \mathrm{m}^{-3}\right]$,

$t$-przyrost czasu [min].

Gdy wartość FED we wzorze (1) wynosi 1, przyjmuje się, że stężenie gazowych substancji toksycznych byłoby śmiertelne dla 50\% narażonych na ich działanie zwierząt w określonym czasie ekspozycji na dany czynnik, co stanowi wartość $L C_{50}$.

W normie ISO 13571:2012 ujęto wzór dla gazów duszących, wedle którego określa się wartości FED:

$$
\begin{aligned}
& \mathrm{FED}=\sum_{t_{1}}^{t_{2}} \frac{[\mathrm{CO}]}{35000 \mu l \cdot 1 \cdot \mathrm{min}^{-1}} \Delta t+ \\
& +\sum_{t_{1}}^{t_{2}} \frac{\exp ([\mathrm{HCN}] / 43)}{220 \mathrm{~min}} \Delta t
\end{aligned}
$$

gdzie:

[CO], [HCN] - ułamki objętościowe tlenku węgla i cyjanowodoru $\left[\mu 1 \cdot 1^{-1}\right]$.

Obliczenia dla gazów drażniących są praktycznie analogiczne, z tym że wykorzystuje się chwilowe stężenie gazów, a nie wartość skumulowaną. W przypadku właśnie tych gazów skuteczna dawka FED wynosi 1, gdy przeciętny zdrowy człowiek w wyniku podrażnienia sensorycznego i/lub górnych dróg oddechowych staję się niezdolny do samodzielnej ucieczki. Ogólne równanie dla gazów drażniących jest następujące:

$$
\begin{aligned}
& F E C=\frac{f_{\mathrm{HCl}}}{\mathrm{F}_{\mathrm{HCl}}}+\frac{f_{\mathrm{HBr}}}{\mathrm{F}_{\mathrm{HBr}}}+\frac{f_{\mathrm{HF}}}{\mathrm{F}_{\mathrm{HF}}}+\frac{f_{\mathrm{SO}_{2}}}{\mathrm{~F}_{\mathrm{SO}_{2}}}+ \\
& +\frac{f_{\mathrm{NO}_{2}}}{\mathrm{~F}_{\mathrm{NO}_{2}}}+\frac{f_{\text {acrolein }}}{\mathrm{F}_{\text {acrolein }}}+\frac{f_{\text {form. }}}{\mathrm{F}_{\text {form. }}}+\sum \frac{f_{\text {irritant }}}{\mathrm{F}_{\text {irritant }}}
\end{aligned}
$$

gdzie:

$f_{\mathrm{HCl}, \mathrm{HBr} . . .}$ - średnie stężenie produktów toksycznych $\left[\mu 1 \cdot 1^{-1}\right]$,

form. - formaldehyd, acrolein - akroleina, irritant - inne gazy drażniące, F - tabelaryczna wartość stężenia, która uniemożliwia bezpieczną ewakuację $\left[\mu 1 \cdot 1^{-1}\right]$.

\section{Podsumowanie}

Analiza literatury uprawnia do stwierdzenia, że problem oszacowania toksyczności środowiska pożarowego w aspekcie bezpiecznej i skutecznej ewakuacji w budynkach jest niezmiernie trudny do realizacji. Oprócz problemów omówionych w artykule dodatkowe trudności w oszacowaniu rodzaju i ilości toksyn wynikają z tego, że w pożarze jest ciagły ruch gazów na skutek różnicy ciśnień produktów spalania i otaczającej atmosfery. Dochodzi do tego trudny do przewidzenia przebieg pożaru. Skutki oddziaływań toksyn na organizm ludzki mogą być różne (niezależne, sumujące, synergistyczne i antagonistyczne). Brak 
jest również danych dotyczących skutków jednoczesnego oddziaływania temperatury, dymu i gazów toksycznych na organizm ludzki.

\section{Literatura}

Hull, T.R. i Paul, K.T. (2007). Bench-scale assessment of combustion toxicity - A critical analysis of current protocols. Fire Safety Journal, 42, 340-365.

Hull, R.T. i Keith, T.P. (2007). Bench-scale assessment of combustion toxicity - A critical analysis of current protocols. Fire Safety Journal, 42, 340-365.

Kobes M., Helsloot, I., de Vries, B. i Post, J.G. (2010). Building safety and human behaviour in fire: A literature review. Fire Safety Journal, 45, 1-11.

ISO 13571:2012. Life-threating components of fire. Guidelines for the estimation of time to compromised tenability in fire [Zagrażające życiu komponenty pożaru. Wytyczne dotyczące oszacowania czasu wystapienia objawów upośledzenia fizjologii podczas pożaru].

PN-88/B-02855. Ochrona przeciwpożarowa budynków. Metoda badania wydzielania toksycznych produktów rozkładu i spalania materiałów.

PN-EN 13501-1+A1:2010. Klasyfikacja ogniowa wyrobów budowlanych i elementów budynków. Część 1. Klasyfikacja na podstawie wyników badań reakcji na ogień.

PN EN 60695-7-1:2007. Badanie zagrożenia ogniowego. Część 7-1. Toksyczność lotnych produktów spalania. Wytyczne ogólne.

Rozporządzenie Ministra Infrastruktury z dnia 12 kwietnia 2002 r. w sprawie warunków technicznych, jakim powinny odpowiadać budynki i ich usytuowanie (Dz.U. 2002 nr 75, poz. 690).

Stec, A.A. (2017). Fire Toxicity - The elephant in the room ? Fire Safety Journal, 91, 79-90.

Sychta, Z. [b.d.]. Metoda wydzielania toksycznych produktów podczas rozkładu termicznego i spalania materiałów. Instrukcja do stanowiska [b.m.wyd.].

\section{Streszczenie}

Ocena toksyczności środowiska pożarowego - problem nie do rozwiązania? Według światowych statystyk toksyczne produkty spalania, które powstają podczas pożarów, są najczęstszą przyczyną zgonów, około $70-80 \%$ wszystkich ofiar śmiertelnych. Należy zauważyć, że jest to jedna z najmniej rozpoznanych dziedzin wiedzy z obszaru inżynierii bezpieczeństwa pożarowego. W związku $\mathrm{z}$ powyższym ocena toksyczności środowiska pożarowego jest jednym z najważniejszych aspektów, który wymaga analizy i oceny $z$ punktu widzenia bezpieczeństwa pożarowego. W pierwszej części artykułu przedstawiono aktualny stan problematyki bezpieczeństwa pożarowego. Omówiono metodę pomiaru toksycznych produktów, które powstają podczas rozkładu termicznego i spalania. W drugiej części dokonano analizy rozwiązań tego problemu, które są opisane w wybranych dostępnych materiałach bibliograficznych, tj. normach, publikacjach. Z treści artykułu wynika, że przedmiotowa problematyka wymaga gruntownych zmian i uregulowań w Polsce i na świecie.

\section{Summary}

Assessment of fire environment toxicity - an unsolvable problem? Global statistics indicate that toxic combustion products generated during fires are the most frequent cause of fatalities, i.e. $70-80 \%$ of all fatalities. It should be emphasises that this is one of the least studied fields of knowledge as regards fire safety engineering. Consequently the problem of assessing the fire environment toxicity is one of the most important, and perhaps even the most important aspect that requires analyses and evaluation from the fire safety viewpoint. The first part of the article presents the current state of issues mentioned above. The author discussed measurement methods of toxic products that 
are being generated during thermal decomposition and combustion. The second part presents a review of available solutions in this respect, which have been outlined in selected available documents, such as for example standards and publications. The contents of this paper make it clear that the mentioned issues require comprehensive changes and the adoption of new regulations in this respect both in Poland and worldwide.

\section{Author's address:}

Waldemar Jaskółowski

Szkoła Główna Służby Pożarniczej

Wydział Inżynierii Bezpieczeństwa Pożarowego 01-629 Warszawa, ul. Słowackiego 52/54

Polska

e-mail: wjaskolowski@gmail.com 